\title{
Discourse Control Strategies in Police-Suspect Interrogation in Nigeria
}

\author{
Raifu Olanrewaju Farinde ${ }^{1}$, Oluranti Adekemi Olajuyigbe ${ }^{1} \&$ Adegbite Matthew $^{1}$ \\ ${ }^{1}$ Department of English, Adeyemi College of Education, Ondo, Nigeria \\ Correspondence: Raifu Olanrewaju Farinde, Department of English, Adeyemi College of Education, P.M.B 520, \\ Ondo, Ondo State, Nigeria. E-mail: mikh_fad75@yahoo.com
}

$\begin{array}{ll}\text { Received: November 20, } 2014 & \text { Accepted: December 11, } 2014 \quad \text { Online Published: January 27, } 2015 \\ \text { doi:10.5539/ijel.v5n1p146 } & \text { URL: http://dx.doi.org/10.5539/ijel.v5n1p146 }\end{array}$

\begin{abstract}
This study examined the discourse control strategies in the use of English in police-suspect interrogation in Nigeria with a view to identifying the themes in the interrogation discourse and discussing the pragmatic functions of the dominant discourse control strategies employed by the police interrogators. The data gathered were transcribed and analysed, using Thomas' metapragmatic model. The result indicated that assault, affray, house breaking, obtaining by false pretence (419), abduction, and robbery were the common themes in the discourse. Analysis revealed further that the investigating police officers (IPOs) employed illocutionary force indicating devices for intimidation and coercion of suspects while they used discoursal indicators, meta-discoursal comments, and upshots and reformulations as discourse control strategies. The study concluded that police-suspect interrogation is largely slanted in favour of the police interrogators and that police interrogation is a peculiar discourse genre where there is interplay of power asymmetry and dominance.
\end{abstract}

Keywords: interrogation, police, suspect, asymmetry, strategies, discourse, coercion

\section{Introduction}

As part of the expanding field of forensic discourse, there has been, in recent times, an increasing focus on the process of the police interrogation, especially use of language by police interrogators. The analysis of language use in such communication encounter is important because pieces of information emanating from such discourse are gathered in evidence and can later be used in court. How language is used within interrogation setting can have serious consequences for the suspect. Starting from effecting arrest, writing of statement, reading of caution, interrogation per se, prosecution to dispensing of justice, language is a veritable tool in the hand of the investigating police officer. Its (mis)use has grave consequences for the suspect.

Shuy $(1997$; 2005) identifies the problem of comprehensibility as one of the many linguistic problems in the examination of police caution or Miranda warnings and interrogation by extension. In a follow-up study, Shuy (1998, p. 53) points to the fact that even when the police read the caution directly from a source text, their performance as readers is always so poor that comprehension of the caution message is adversely affected.

In addition to comprehensibility problem, Shuy (1997) also points to language of coercion as a major problem in police interrogation of suspects. He states that this could come in form of verbal dominance or control.

Intimidation can result both from physical and from verbal force. If suspects are dominated by verbal force without regard for their individual desire or volition, the result is coercion as much as it would be from physical force. (p. 179)

Berk-Seligson (2002) contends that from a discourse analytical point of view, each police interrogator tends to "recycle" the topics of interest to him/her (the crime and the suspect's involvement). So all discourse strategies employed by the interrogator are geared towards obtaining confession from the suspect. Citing Aubury and Caputo (1980), Berk-Seligson (2002, p. 140) claims that this approach (recycle) has been referred to, in the language of professional criminal investigators, as "constant repetition of one theme" which consists of "repeating the same questions or line of questioning over and over again".

Another linguistic problem in police interrogation originates from the fact that police officers are allowed to paraphrase the message contained in the caution or Miranda. The danger here, as Cotteril (2002) has shown in her analysis of the "police caution", the United Kingdom's equivalent of the United States of America's Miranda 
warnings, is that there is great variability in the way that different police officers paraphrase the caution, and that in the process of paraphrasing, the police often make the caution/Miranda warnings less comprehensible than they originally are.

\section{Review of Related Background Literature}

\subsection{Power Relationship in Police Interrogation}

The centrality of language to human communication cannot be over-emphasized. In fact, the use of language for the expression of one's feelings, ideas and thoughts is an attribute that humans do not share with any creature. However, the use of language in human communication encounters is determined by a number of factors. For instance, the power differential between interlocutors, more often than not, determined by their social standing constrains what each interactant contributes or says in interpersonal communication situations. This is more so in a communication encounter that involves unequal interlocutors e.g., Police-Suspect interrogation. Such communication situations demonstrate the connection between Language and Power.

Fairclough (1989, p. 46) explores various dimensions of the relation of power and language. He focuses on two major aspects of the power language relationship: Power in discourse and Power behind discourse. Power in discourse has to do with powerful participants controlling and constraining the contributions of non-powerful participants. Fairclough (1989) believe that this constraint rests on three factors which are (i) contents (on what is said or done); (ii) relations (the social relations people enter into in discourse); (iii) subjects (the subject positions people can occupy).

Power in discourse has to do with asymmetrical relationships. One group will be able to control the other group. So power can feature the ability of one person able to control and enforce the other. Power also has to do with the ability of one person able to assert his/her influence and will on the other. According to Lukes (1974) in Wang (2006, p. 531), the exercise of power shows that one affects or coerces another person in a manner contrary to another person's interest.

Thus, the discourses of unequal encounter such as-between teacher and student, doctor and patient, police and suspect and lawyer and witness-where the power relationship is overt and institutionalized are all examples of power in discourse. Furthermore, casual conversation such as radio-talk, family discourse, discourse and gender where power is covert and usually contested also belong to power in discourse.

Power behind discourse on the other hand does not belong to face-to-face discourse such as all the examples above. This kind of power is a hidden power. Power behind discourse, according to Fairclough (1989) is the idea that the whole social order of discourse is put together and held together as a hidden effect of power. Institutionalized discourse such as legal discourse, doctor/patient talk, and police-suspect talk are all examples of discourses where power is highly prominent. But the power behind the conventions of these discourses does not belong to these institutions themselves but to the power holders in the institutions. These power-holders are also responsible to some powerful group of people who control and dictate to them. A group of people are behind the scene pulling the strings of power. However, since this study is based on face-to-face discourse and language can only be analysed on power in discourse, the focus of this study will be on power in discourse.

Van Djik (2001) defines social power as control and holds that groups have power if they are able to control the acts and minds of other groups. "Different types of power may be distinguished in accordance with the different resources employed to exercise power. Members of more powerful social groups have the precedence to access and control over some public discourse. Thus, professors control scholarly discourse, teachers-educational discourse, Journalists-media discourse, Judges and lawyers-legal discourse, and politicians-policy and other public political discourse" (Wang, 2006, p. 531).

Flowerdew (1997) gives the following premises on which power is based which summarise power in all its ramifications:

1) Power is exercised by individuals and therefore involves choice, agency and intention.

2) The interest of the powerful and less powerful are likely to differ and therefore the exercise of power may lead to conflict, resistance, and coercion.

3) On the other hand, individuals involved in power relations may not always be aware of the power they wield or are subjected to.

4) Although, power can be seen as productive, enabling, and as a positive capacity for achieving social ends, it is very often used negatively, and the literature on language and power has primarily concentrated on this negative aspect and how the powerful exploit the less powerful. 
5) In the modern world, power is exercised increasingly by linguistic means.

From the above analyses, we can see that power is a relative concept between the oppressed and the oppressor.

Buttressing the foregoing, Fowler et al. (1979) aver that language is an integral part of social process. It establishes, lubricates and sustains relationships albeit at varying degrees and with varied power relations. Power can be found in any conversation of everyday life. Ideal dialogue (as coined by scholars such as Maranhao, 1990; Crowell, 1990; Linell, 1998) which is supposed to be exempted from power is believed to be unattainable and unrealistic. "Power is coherent in all dialogue whether in casual conversation or in institutional settings" (Wang 2006, p. 929). Although, the degree of power manifested in different contexts differs greatly.

Fowler et al. (1979) equally hold the opinion that the relation between form and content is not arbitrary or conventional but form signifies content. This apparently denotes that language is a social activity and it is ideologically motivated.

Power is always a key factor in discourse interaction. This is moreso in institutional discourses like teacher-student, doctor-patient, barrister-witness, police-suspect etc. Onadeko (2007, p. 126) substantiates this view with findings from a study he carried out on speech rights manipulation in Nigerian magistrate court talk. He discovers that participants who occupy + HIGHER role and MIDHIGHER role initiate three-slot exchanges in dyadic and triadic speech events in the courtroom. The magistrates occupy the + HIGHER role while the lawyers and the investigating police officers occupy the MIDHIGHER role and the suspects and witnesses occupy the - HIGHER role. The foregoing presents courtroom speech right as grossly asymmetrical.

In the same vein, Thomas (1985, p. 766) argues that the power relationship obtaining between the participants in an interaction and the institutional norms within which that interaction takes place are central to the way in which the discourse is developed and individual utterances interpreted. In the dyadic interactions she works with, the pragmatic parameters of power, social distance and degree of imposition are held relatively constant and they greatly define interactants' role relationships. In each case, the interaction takes place in the dominant participant's "home territory" (e.g., the headmaster's office, the Chief Inspector's office, the magistrate's court etc.). She finds that in each case, the dominant participant uses certain discourse strategies to minimise the discourse opportunities of the subordinate participant and to impose and control the discourse topics. These, she called discourse controllers and meta-pragmatic acts. These strategies are going to be explained in greater detail subsequently in this work because they form part of the theoretical framework for this study.

Heydon (2005) equally presents a critical analysis of police interrogation in Australia. She investigated the roles of the police in police-suspect interrogation in relation to both the negotiation of power relations between participants and the fulfillment of institutional requirements. Combining the analytical tools provided by Interactional Sociolinguistics and Conversation Analysis (CA), Heydon investigated recordings of police interrogation of adult suspects. She uses Critical Discourse Analysis (CDA) to interpret the results of the descriptive analysis of the data and discovers that the power relationship between the participants is asymmetrical.

In agreement with Onadeko (2007), Farinde (2006; 2008; 2010) asserts that power relationship among participants in the Nigerian courtroom discourse is very asymmetrical. He claims that courtroom discourse rules and regulations favour the judges, barristers, and the prosecutors while the defendants and witnesses are at the receiving end. Police-suspect discourse too, being an institutional discourse type, is always slanted in favour of the investigating police officers who have institutional authority.

\subsection{Police Caution/Miranda Warnings}

Caution and Miranda are two different words used to express the same idea in England and the United States of America respectively. Caution is also used in Australia, Nigeria, and most commonwealth nations. Caution or Miranda enshrines the constitutional rights of custodial suspects. A suspect is supposedly innocent until he/she is proved otherwise. To this effect, his/her rights especially as they relate to interrogation are intact and he/she should be made to understand this by the police interrogator. These rights, world over, are always trampled upon, especially the right to keep silent or not to say anything during interrogation. Gibbon (2003) cited in Farinde (2008, pp. 48-49) identifies four different kinds of cautions:

1) Caution 1 (used at the beginning of the interrogation process between the police and the suspect e.g., I am going to ask you certain questions which will be recorded on a video-tape recorder. You are not obliged to answer or do anything unless you wish to do so. But whatever you say or do will be recorded and may later be used in evidence. Do you understand that?); 
2) Caution 2 (used when an interrogation has been interrupted and about to commence again e.g., Do you agree that prior to the commencement of this interrogation I told you that I intended asking further questions about this matter?);

3) Caution 3 (another adoption question for video-taped interrogation e.g., What I propose to do is ask you the questions in relation to this matter. My questions and answers given by you will be electronically recorded on tape as the interrogation takes place. Do you understand that?); and

4) Caution 4 (used at the end of the interrogation e.g., Has any threat, promise or offer of advantage been held out to you to give the answers recorded in this interview?).

It is instructive to point out at this juncture that in Nigeria caution 1 is the most commonly used and the last one (caution 4) is observed once in a while. Interrogation sessions recorded in this study buttress this assertion.

Abuse of caution and Miranda warnings by police officers, its structural complexity or its blatant non use is not peculiar to Nigeria. Rogers et al. (2007) study the wordings and sentence complexity of Miranda warnings and waivers in the United States of America (USA). They examine 560 Miranda warnings across USA, using Flesch-Kincaid reading comprehension as a useful metric and discovered that they varied dramatically from jurisdiction to jurisdiction ranging from simple comprehension (i.e., grade 2.8) to requiring postgraduate education.

Gibbons (2003) and Cotteril (2002) equally point to the complexity and lopsidedness of the wordings of police caution. This is even complicated by the fact that police officers themselves are not specially trained in language technicalities. For instance, police officers in their delivery of caution to suspects always confuse the intended meaning of "advice" with the more threatening connotation of a "warning". Gibbons (2003, p. 191) suggests a simpler version of police caution:

I am going to ask you some questions.

You do not have to say or do anything if you do not

want to. Do you understand?

We will record what you say or do. We can use this recording in court. Do you understand?

The problem of police caution abuse is attributable to power inequality between the two parties involved in police interrogation.

\section{Data Collection}

Thirty (30) police-suspect interrogation sessions from six purposively selected police stations comprising three urban and three sub-urban centres from the Ondo Area Command of the Ondo State Police Command were observed and recorded for this study. The urban centres were Ondo, Ore and Okitipupa while the sub-urban centres were Okeigbo, Bolorunduro and Odigbo. The towns were purposively chosen based on their geographical spread across the Ondo Area Command as well as their population and commercial advantages. The justification for sampling data across urban and sub-urban centres was to observe whether there would be differences in the themes occurring in the interrogation sessions in these centres. All the interrogation sessions recorded for this study were conducted mainly in English and the subjects were adults (18 years and above).

The process of gathering data for this study involved the use of research instrument such as tape-recording, interview and personal observation. Having sought and secured permission from the Ondo Area Commander, thirty interrogations of suspects sessions were witnessed and recorded by the researcher across the Ondo Area Command. Unstructured oral post-recording interview was used in few instances to clarify observed extra-linguistic cues during the interrogation sessions. The interrogation sessions were closely observed through participant observation. This lent additional credence to the information gathered through tape-recording and oral interview. The data gathered for this research work were transcribed and analysed, using Brown and Levinson's Politeness model. In analysing the data, items were scored on the basis of frequency distribution and simple percentages. The data were recorded in a tabular form to facilitate easy interpretation and analysis. Percentages, as used for analysis in this study were determined by simply dividing the frequency of each item in the table by the total number of items and the quotient was then multiplied by 100 . This method was considered good because it facilitated clear-cut analysis and logical inferences.

$$
\text { Frequency }=\frac{\text { Total Number of an item }}{\text { Total Number of items in its category }} \times \frac{100}{1}
$$




\section{Theoretical Framework}

\subsection{The Speech Acts Theory}

John Langshaw Austin (1911-1960) was the proponent of the Speech Acts Theory. The main thrust of this theory is that "human utterances perform certain acts" as against the hitherto held view that the main function of sentences is to state facts along the line of being true or false (Saeed, 2003, p. 223). Austin claimed that several sentences are neither true nor false. But he particularly focused on one of these sentences which he called "performative utterances". He identified the qualities of such utterances as:

1) Though they may take the form of a typical indicative sentence, performative sentences are not used to describe (or "constate") and are not true or false; they have no truth-value.

2) To utter one of these sentences in appropriate circumstances is not just to "say" something, but rather to perform a certain kind of action.

Austin's philosophy of language was crystallised and put in proper perspective in his work How to Do Things with Words which was posthumously published in 1962. The speech act theory has since been given scholarly attention by other researchers who have worked on it by ways of modification or extension. They include Searle (1969), Sadock (1974), Bach and Harnish (1979), Gazdar (1981). However, we are going to discuss J. L. Austin's and J. R. Searle's contributions in this study.

Austin distinguishes performative from constative statements. But our focus will be more on peformative because it is more relevant to this study. According to Austin (1962), constative utterances state facts, describe situations, events and state of affairs. And true-false test applies to them. Performative utterances, on the other hand, are used to carry out actions. Such statements are not descriptions and cannot be said to be true or false. Let us consider the sentences below:

1) I declare this meeting open.

2) I promise to marry you.

3) I name the child Ogooluwa.

4) I sentence you to five years imprisonment.

The four sentences above, in Austin's classification, are performative utterances because they do not each give information or describe the state of affairs but they are in themselves a kind of action, Saeed (2003). In each case, we can insert the adverb hereby before the verb to stress its function. They are also examples of explicit performative because the verb that performs the action in each of the sentences is overtly stated. Austin also identified implicit performative utterances in which case, there will be no performative verb overtly expressed. For instance, let us consider the examples below:

\section{I will come to the party.}

I am going to Lagos.

Instead of testing a performative utterance along the true-false paradigm, Austin stated that a performative that works is called felicitous and one that does not is infelicitous. For a performative utterance to be felicitous or otherwise, Thomas (1995) cited in Adeboye (2010, pp. 33-34) claims that Searle (1969) gives four conditions namely: preparatory, propositional, sincerity and essential conditions. Adeboye (ibid) discusses them as follows:

1) Preparatory conditions specify the features of the context required for the performance of a speech act. For instance, a promise demands that the hearer would like the action done and that the speaker knows this, but it is not obvious whether the speaker will perform the action in the normal course of events; for assertion, that the speaker has the evidence of truth of what he/she says and that it is not obvious whether the hearer knows the fact.

2) Propositional conditions state the features that need to be considered in dealing with the meaning of an utterance. For example, while apologies require that one flash backwards (to the past); promises require one to look forward (to the future). This implies that one is expected to apologise for having done something wrong; while one promises to do what is yet to be done.

3) Sincerity conditions specify the wants and beliefs of the speaker. The sincerity condition for a promise is that the speaker intends to act; for a request, that he/she wants the hearer to act; and for an assertion, that he/she believes what is said.

4) Essential conditions refer to the conventional way in which the utterance made is taken to be an effort at getting the hearer to do something. Under these conditions, the speaker intends that the utterance will count as 
promise, a request, an assertion, etc. and that the hearer would be informed of that intention whether he/she is sincere or not.

Austin also proposed that a speech act has three facets: locutionary act, illocutionary act and perlocutionary act. In the words of Saeed, (2003, p. 228) "the speaker says something (locutionary act), the speaker signals an associated and effect on the listeners or the participants". Locutionary act, therefore, is the production of a meaningful linguistic expression, while illocutionary act is the action intended to be performed by the speaker in uttering a linguistic expression, by virtue of the conventional meaning associated with it, and perlocutionary act is the bringing about of consequences or effects on the audience through the uttering of a linguistic expression, such consequences or effects being special to the circumstances of the utterance.

Expanding the speech act theory further, Austin identified five types of speech acts. They are verdictive, exercitives, commissives, behavatives, and expositives. Searle (1969) criticizes Austin's classification on the account of too much overlapping. He then came up with his own five speech act types: representatives (assertive), directives, commissives, expresives, and declarations (declaratives). However, we shall illustrate Searle's classification only in this study as identified above:

1) Representatives (assertive): They commit the speaker to the truth of the proposition expressed by asserting, claiming, stating, concluding. They express the speaker's belief e.g.,

a) I am a Nigerian.

b) There is God.

2) Directives: These are attempts by the speaker to get the addressee to do something. They express the speaker's desire by ordering, requesting, questioning etc. e.g.,

a) Get out of this room.

b) Lend me $\$ 1,000$

3) Commissives: Commit the speaker to some future course of action. They express the speakers intention by promising, pleading, threatening, refusing etc. e.g.,

a) I promise to give you 20,000 tomorrow.

b) I will beat you.

4) Expressives: They express a psychological state. They express the speaker's emotion by apologising, blaming, congratulating etc. e.g.,

a) I thank you so much for your help.

b) I congratulate you on your promotion.

5) Declarations (declaratives): They effect immediate changes in the institutional state of affairs and this tends to rely on elaborate extra linguistic institutions by excommunicating, declaring war, christening, firing from employment. e.g.,

a) You are fired.

b) I take you as my husband.

Though other scholars have contributed to the development, modification, and extension of the speech act theory, the contributions of J. L. Austin (1911-1960) and J. R. Searle continue to be reference point in speech-act theory.

\subsection{Thomas' Metapragmatic Acts Postulation}

The theoretical framework for this work is supported with Thomas $(1985,1986)$ meta-pragmatic acts postulation. Thomas' meta-pragmatic acts are especially good for the analysis of institutional dyadic discourse of unequal participants.

Thomas (1985, 1986), in her discussion of institutional dyadic communication encounters involving unequal participants, identifies some speech acts which she refers to as meta-pragmatic acts. Four of these speech acts are identified, analysed and discussed in this study. They are: (i) Illocutionary force indicating devices (IFIDs), (ii) Discoursal indicator, (iii) Meta discoursal comments and, (iv) Upshots and Reformulations.

The term IFID, according to Thomas (1985, p. 769), refers to “... any expression whose sense determines that a literal utterance of a sentence containing a certain occurrence of that expression has a given Illocutionary force".

Discoursal Indicators are best thought of as the discoursal counterpart of the IFID, since they are surface level markers of the speaker's discoursal intent. They are used principally in order to establish the purpose and nature 
of the talk and to define the topic boundaries of the interaction (Thomas, 1986). Farinde (2008, p. 197) adds that discoursal indicators are used to make it abundantly clear in the surface structure of the dominant speaker's utterances what their intended illocutionary force are. It, in effect, limits the discoursal option of the subordinate participant.

Meta discoursal comments are used by the dominant participant in order to keep the subordinate from wandering from the previously established topic/path, by disallowing contributions which do not contribute to the dominant participant's discoursal or social goals (Thomas, 1986).

Upshots and Reformulations: upshot is a brief summary by the dominant speaker of a long contribution by the subordinate while reformulation refers to presentation of H's (hearer's) utterance in unambivalent terms, in response to which $\mathrm{H}$ is required to make clear or simply to confirm the intended pragmatic force of his/her utterance Thomas $(1985$, p. 773$)$

It is the belief of the researchers that the model is sufficient to explain and analyse data generated in this study in respect of their pragmatic functions in police-suspect interrogation.

\section{Analysis}

We are going to discuss the pragmatic functions of the four meta-pragmatic acts identified in this study. The discussion will start with the most frequently used of the acts to the least used (i.e., discoursal indicator, IFIDs, Upshot and reformulation and meta-discoursal comments). Table 1 below shows the frequency distribution of the pragmatic acts.

Table 1. Frequency distribution of the meta-pragmatic acts in the discourse

\begin{tabular}{llll}
\hline S/N & Meta-pragmatic Acts & Frequency & Percentage \\
\hline 1 & Discoursal Indicators & 32 & 36.0 \\
2 & IFIDs & 25 & 28.4 \\
3 & Upshots and Reformulation & 19 & 21.6 \\
4 & Meta discoursal comments & 12 & 14.0 \\
& Total & $\mathbf{8 8}$ & $\mathbf{1 0 0}$ \\
\hline
\end{tabular}

Table 1 above shows distribution of the meta-pragmatic acts identified in the discourse. It shows that discoursal indicators are the most frequently used meta-pragmatic act in the discourse with a frequency of $32(36.0 \%)$. Next to discoursal indicator is illocutionary force indicating devices (IFID) which has 25 occurrences (28.4\%). Upshots and reformulations have 19 appearances (21.6\%) while meta-discoursal comments accounts for 12 instances (14.0\%).

\subsection{Discoursal Indicator}

Discoursal indicators are surface level marker's of the speaker's discoursal intent. They are used mainly to establish the purpose and nature of the talk and to define the topic boundaries of the interaction. It, in effect, limits the discoursal option of the subordinate participant.

Discoursal indicator in police interrogation, as it is in all other discourse of unequal encounter, is a discourse control power that the dominant participant uses to determine topic of discourse and informational content of the subordinate's contribution. In this case, the IPO sets the pace by opening new topics and closing old ones when he feels they are not leading to achieving his discoursal intents. He equally limits the suspect's contribution and pilots him, with the use of discoursal indicators, to supplying pieces of information relevant to his predetermined discoursal goal. Let us consider the examples below:

\section{IPO: When they said they (police) were looking}

For you, what did they say you did?

Susp: They said I stole laptop and that I have sold it. They

said they were coming from the person I sold it to.

so they said I should follow them to the station.

IPO: Eh eh, what happened after that?

Susp: So, when we got to the police station, we now went

to the person we sold the laptop to. 
IPO: unnh unnh.

Susp: When we got there, em, em after we got there...

IPO: (Cuts in) You stole the laptop or not?

Susp: I don't know, I don't know when they stole it.

I don't know anything sir.

IPO: What I am asking you is that do you know anything about the stolen laptop or not?

(Ex. 24, Text 3, App. 1)

\section{IPO: When did you see Ajayi last?}

Susp: Me and Ajayi no be friends now. I use to see him any time he is passing in front of our house.

IPO: You are not friends! I am not saying you people are friends.

When did you see Ajayi last? That is the question I asked you.

(Ex. 25, Text 14, App. 1)

IPO: Do you know Lara, that small fine and fair complexioned girl?

Susp: $\quad$ Em $-\mathrm{m}-\mathrm{m}-\mathrm{m}$, she is my girl friend.

IPO: Now, I want to ask you a few questions concerning her.

Susp: Okay.

IPO: For how long have you been relating together?

Susp: Up to six months now.

(Ex. 26, Text 9, App. 1)

In each of the examples above we can see how the IPO uses the discourse indicators to direct the interlocution in each case. The IPO's utterance determines and as well limits the contribution of the suspect. And whenever the latter seems to be up to some pranks or feign lack of understanding, the IPO restates/re-opens the topic to which he expects contribution from the suspect, as the case in example 26 above.

\subsection{Illocutionary Force Indicating Devices}

Illocutionary force indicating device refers to any expression whose sense determines that a literal utterance of a sentence containing a certain occurrence of that expression has a given illocutionary force.

Instances of utterances with IFIDs in police interrogation analysed in this study further reveal that the IPO who is the dominant speaker, holds higher power and authority than the suspect. IFID is therefore a pragmalinguistic means of manifesting the asymmetrical power relationship between participants in the discourse of unequal interactants.

IFIDs are also intimidation strategies used by the IPOs to throw suspects off-balance psychologically. The illocutionary effect of this strategy on the psyche of suspects is overwhelming. For instance, let us see how the illocutionary effect of the utterances of the IPO in the example below makes the suspect to commit himself.

IPO: How many of you went to Mr. Bello's house together with Otuga?

Susp: Me I no follow them. I no follow dem sam sam (I did not follow them. I did not follow them at all).

IPO: Who are they that went there?

Susp: I don't know sir (suspect's phone rings).

IPO: You still dey received call (you are still receiving call). See this criminal. You don't know the gravity of the offence you have committed. See how he is looking at me. Bring that handcuffs. Give me that pistol. I will condemn your leg.

Susp: Sorry sir. I am sorry sir. I am sorry sir.

IPO: I am putting it to you that you were among those robbers that went to that man's house to rob him.

Susp: Me I no follow dem that day o. (I did not follow them that day) 


\section{(Ex. 27, text 29, App. 1)}

The above exchange points to the psychological context of police interrogation where rifle, pistol, handcuffs, baton and cell are present. All these elements are used to the advantage of the IPOs. The illocutionary force of the IPO's utterance in ex. 27 above is fear-inducing on the suspect. This is manifested in the suspect's turn sequence. The suspect's first response "I did not follow them at all" has polar relationship to his last response "I did not follow them that day". The request by the IPO for handcuffs, and pistol with which he threatens to condemn the suspect's legs achieved the pragmatic effect of evoking guilt in the suspect. This makes him (the suspect) to say "sorry sir, I am sorry sir...".This breaking or complicity-invoking response encourages a follow-up IFID utterance "I am putting it to you that..." from the IPO. In response to this, the suspect inadvertently or decidedly says "I did not follow them that day". This implies that he had, at least, followed them one time before. This utterance is revealing and vital to the IPO's utmost goal of confession. The suspect's response could be attributed to the fact that he thinks that he has only two options: to say the truth or to have his legs condemned with pistol and baton.

IFID is an intimidation and coercion strategy. Its pragmatic force is always powerful on the suspects. As a result of this, the IPOs always deploy IFIDs to make suspects admit their guilt at the confession/breaking point. Examples 28 and 29 below corroborate this fact:

IPO: Did you inform Ojo before you took the goat?

Susp: He was not around when I took it.

IPO: Ojo was not around. You got to a place and just carried a goat because that man is you friend. You went to sell it because you wanted to eat. It that not so? I am putting it to you that what you have done amounted to stealing. Do you believe that?

Susp: Yes sir.

(Ex. 28, Text 4, App. 1)

IPO: Anyway, what did she eat in your place?

Because she has been complaining about her stomach since she left your place.

Susp: She didn't eat anything strange in my place sir.

IPO: Do you know that what you have done is wrong?

Susp: I am sorry sir.

IPO: I put it to you that what you did amounted to abduction and you have erred in law.

Susp: Yes sir.

IPO: Officer, detain him.

(Ex. 29Text 26, App. 1)

In examples 28 and 29 above, we can see that IFIDs are used to make the suspects admit and confess their guilt. The implicature of the suspect's first utterance in example 28 is that he took (stole) the goat (whether Ojo was around or not). Having secured this somewhat express confession, the IPO provides an upshot (a brief summary of the suspect's long contribution) which ends with "Is that not so?". The upshot is used to disambiguate the long utterance of the suspect and to actually confirm its intended pragmatic force. Given the implicature of all these, the illocutionary force of the IPO's last utterance is so strong and compelling that the suspect has to admit his guilt with a "yes sir" response.

In example 29 on the other hand, the suspect's guilt-indicating utterance of "I am sorry" necessitated the illocutionary force indicating utterance of the IPO "I put it to you..." which pragmatically forces the suspect to the admittance of his guilt.

\subsection{Upshots and Reformulations}

Upshot is a brief summary by the dominant speaker of a long contribution of the subordinate while reformulation refers to presentation of H's (hearer's) utterance in unambivalent terms, in response to which $\mathrm{H}$ is required to make clear or simply to confirm the intended pragmatic force of his/her utterance.

In police interrogation, upshots and reformulations are discoursal disambiguation techniques and they are mostly initiated by the IPO who wants to get the 'fact' clear as they are presented by the suspect. Let us consider these examples: 
IPO: Who did you say you sold it to?

Susp: Engineer Michael

IPO: Who introduced you to Engineer Michael? How did you know him?

Susp: Tunrayo, one of his workers took me to him.

IPO: Is Tunrayo an Engineer too?

Susp: Yes sir, one of his workers.

IPO: Is Tunrayo a man or a woman?

Susp: He is a man.

IPO: So, it was Engineer Tunrayo that introduced you to Engineer Michael.Abi?

Susp: Yes sir,

(Ex. 30, Text 3, App. 1)

In example 30 above, we can see that the IPO's last turn (utterance) presents a summary of the main gist of the exchange. If this does not represent the suspect's thought, he has the opportunity to clarify or restate the intended pragmatic force of his contribution. But in the example above, he simply confirms. Ex. 31 below further supports this explanation. The pragmatic function of this act is that of giving the suspect the opportunity to admit or confess to committing a crime personally.

IPO: Did you inform Ojo before you took the goat?

Susp: He was not around when I took it.

IPO: Ojo was not around. You got to a place and just carried a goat because that man is you friend. You went to sell it because you wanted to eat. Is that not so?

\section{Susp: Yes sir.}

(Ex. 31, Text 4, App. 1)

Example 31, as well as 30, presents the interrelatedness of the two metapragmatic acts (upshot and reformulation). While upshot presents a brief summary of the suspect's long story, reformulation is always the follow-up statement that comes after the upshot and which carries greater force that always leaves the suspect with virtually no alternative other than to admit his/her obvious guilt. "Abi?" and "Is that not so" in examples30 and 31 respectively serve this purpose.

\subsection{Metadiscoursal Comments}

Metadiscoursal comments are used by the dominant participant in order to keep the subordinate from wandering from the previously established topic/path, by disallowing contributions which do not contribute to the dominant participant's discoursal goals. Some of the realisations of metadiscoursal comments in the discourse studied are discussed below:

IPO: Who are the people involved. Tell me.

Susp: The Bros that came to stand as my surety that day now. Oga sebi the Bros give you envelop that day before you help us die the matter. He give you your envelop now.

IPO: You see that envelop he gave me that day. No be envelop matter we dey talk now. Se you hear? (it is not envelop issue that we are discussing now. Is that clear?)We are not talking of envelop now. When you collected the money from Bolaji why didn't you supply him the motor you promised him?

\section{(Ex. 32, Text 13, App. 1)}

In example 32 above, the IPO is serious about unraveling the truth of the matter. But the suspect wants to re-direct the discussion toward "settlement" (bribery) by reminding the IPO of the last time he was given envelop (bribe) by the leader of the suspect's gang. The IPO squarely tells him that that is not the focus of their discussion by telling him that "no be envelop matter we dey talk now". The suspect intentionally wants to elicit cooperation from the IPO by letting him know that it is the 'bros' that gives envelop that is involved. But the IPO sharply turns this down and re-states the focus of their discussion.

Example 33 below further buttresses the fact that metadiscoursal comments are used to make the suspect tow the line of the IPO's discoursal goal. 
IPO: When did you see Ajayi last?

Susp: Me and Ajayi no be friends now. I use to see him any time he passes in front of our house.

IPO: You are not friends. I am not saying you people are friends. When did you see Ajayi last? That is the question I asked.

Susp: I saw him on Friday.
IPO: Which Friday?
Susp: Last Friday?
IPO:

(Ex. 33, Text 14, App. 1)

The background information to the exchange above is that Ajayi and the suspect went to rob on the Friday that the suspect said he saw Ajayi last. So the suspect's first utterance in response to the IPO's question is intended to dissuade the IPO from possible linking of the suspect to the crime or Ajayi who is at large. However, the pragmatic function of the IPO's metadiscoursal comment is that it makes the suspect to supply basic vital pieces of information. Firstly, the suspect's response to the metadiscoursal comment implies that he knows Ajayi and that he saw Ajayi last Friday, the day the crime was committed. This fact is pragmatically manifested in the IPO's next question after the suspect has mentioned the day he saw Ajayi with the discourse marker "okay" (meaning now that you (the suspect) have agreed to these basic pieces of information upon which further interrogation can rest). So it is on this basis that the IPO starts to ask questions that are directly related to the crime until it reaches a crescendo where the suspect is implicated.

In essence, meta-discoursal comment is a dominant participant's discoursal control tool. And it is, more often than not, used in police interrogation to show that the IPO dictates and controls the topic of the discourse.

On a general note, data for this study showed that certain themes are more prevalent in the urban centres in the interrogation sessions. For instance, obtaining by false pretence (419) with $16.7 \%$ was the most prevalent theme in the urban centres closely followed by abduction, house breaking and affray with $13.3 \%$ each. However, assault was the most prevalent theme in the sub-urban centres with $13.3 \%$. The overall percentage, however, show that assault, house breaking and affray with $20 \%$ each were more prevalent at the urban and sub-urban centres.

Going by our findings and observation in this study, we discovered that the four metapragmatic acts identified in the data for this study can further be synthesized and jointly be grouped into two holistic strategies. The first group encompasses strategies that bother on intimidation and coercion which are realized by illocutionary force indicating devices. The second group is discourse control strategies which are realised by discoursal indicators, upshots and reformulations, and metadiscoursal comments.

\section{Conclusion}

This research work has been able to identify the themes occurring in and discourse control strategies dominant in the police - suspect interrogation in the Ondo Area Police Command. It has equally been able to analyse these strategies as well as discuss their pragmatic functions in the discourse. Assault is the most prevalent theme in the interrogation sessions in the sub-urban centers while obtaining by false pretence (419) dominated the interrogation sessions in the urban centers.

This study has also revealed that police interrogation as a discourse act is slanted in favour of the police interrogators. It is also discovered that there is power asymmetry between the IPO and the suspect, the parties in the discourse. This fact is further established by the dominance of illocutionary force indicating devices strategy which is the discourse control tool of the dominant participant. We have seen that the investigating police officers (IPOs) employed illocutionary force indicating devices for intimidation and coercion of suspects while they used discoursal indicators, meta-discoursal comments, and upshots and reformulations as discourse control strategies.

It is hoped that the suggestions and insights emanating from the findings of the study will definitely spur language experts in general and applied linguists in particular to turn their research searchlight in the direction of Forensic Linguistics (study of language in the context of the law). The findings of this study will also enlighten the Nigerian judiciary (Lawyers and Judges) as well as investigative police officers and the Nigeria Police authorities about the pragmatics of language in interrogation and cross-examination by extension. This may bring about a re-orientation that may lead to mounting of specific language courses like pragmatics, discourse 
analysis and stylistics in Nigeria Police colleges. It will also make the judiciary and police authorities see the necessity of enlisting the services (expert opinions) and advice of linguists in knotty language problems in legal settings as it is done in the Western World such as Britain, United State of America, Canada and Australia.

\section{References}

Adeboye, A. B. (2010). A Study of the Pragmatic Use of English in the Spoken Discourse of Police Officers and their Interactants in Osun State. An M. A. Thesis, Department of English, Obafemi Awolowo University, Ile - Ife.

Austin, J. L. (1962). How to Do Things with Words. London: Oxford University Press.

Bach, K., \& Harnish, R. M. (1979). Linguistic Communication and Speech Acts. Cambridge: The M.I.T. Press.

Berk-Seligson, S. (2002). The Miranda Warnings and Linguistic Coercion: The Role of Footing in the Interrogation of a Limited - English - Speaking Murder Suspect. In J. Cotteril (Ed.), Language in the Legal Process. New York: Palgrave Macmillan.

Cotteril, J. (1998). Review of Shuy, Roger W. "The Language of Confession, Interrogation and Deception". Forensic Linguistics, 5(2), 209-214.

Cotterill, J. (2002). Reading the Rights: A Cautionary Tale of Comprehension and Comprehensibility. Forensic Linguistics, 7(1), 4-25.

Crowell, S. G. (1990). Dialogue and Text: Re-marking the Difference. In T. Maranhao (Ed.), The Interpretation of Dialogue (pp. 338-360). Chicago: Chicago University Press.

Fairclough, N. (1989). Language and Power. London: Longman.

Farinde, R.O. (2006). Power Asymmetry in the Language of Nigerian Courtroom Discourse. An Unpublished $\mathrm{Ph} . \mathrm{D}$ Dissertation, University of Wales, Bangor, United Kingdom.

Farinde, R.O. (1997). A Linguistic Study of Police/Accused Discourse. Unpublished M. A. Thesis, University of Ibadan, Ibadan.

Farinde, R. O. (2010). What is Forensic Linguistics. A Paper Presented at the 5th annual National Conference of School of Languages, Adeyemi College of Education, Ondo, Nigeria.

Flowerdew, J. (1997). Reproduction, Resistance, and Joint-Production of Language Power: A Hong-kong Case Study. Journal of Pragmatics, 27, 315-337. http://dx.doi.org/10.1016/S0378-2166(96)00036-7

Fowler, R., Hodge, G., Kress, G., \& Trew, T. (1979). Language and Control. London: Routledge and Kegan Paul.

Gazdar, G. (1981). Speech Act Assignment. In A. K. Jopshi, B. L. Webber, \& I. A. Sag (Eds.), Elements of Discourse Understanding. Cambridge: Cambridge University Press.

Gibbons, J. P. (2003). Forensic Linguistics: An Introduction to Language in the Judicial System. Malden M. A.: Blackwell Publishing Ltd.

Heydon, G. (2005). The Language of Police Interviewing: A Critical Analysis. Houndmills and New York: Palgrave Macmillan.

Linell, P. (1990). Approaching Dialogue: Talk, Interaction and Contexts in Dialogue Perspectives. Amsterdam/Philadelphia: John Benjamins.

Luke, S. S. (1974). Power: A Radical View. London: Macmillan.

Maranhao, T. (Ed.). (1990). The Interpretation of Dialogue. Chicago: University of Chicago Press.

Onadeko, T. (2007). Speech Rights Manipulation in Nigerian Magistrate Court Talk. In M. Olateju, R. Taiwo, \& A. Fakoya (Eds.), Towards the Understanding of Discourse Strategies (pp. 107-129). Ago - Iwoye: Olabisi Onabanjo University Press.

Rogers, R., Kimberly, S. H., Shuman, D. W., Sewell, K. W., \& Hazelwood, L. L. (2007). An Analysis of Miranda Warnings and Waivers: Comprehension and Coverage. Law and Human Behaviour, 31(2),

Sadock, J. M. (1974). Towards a Linguistic Theory of Speech Acts. New York: Academic Press.

Saeed, J. I. (2003). Semantics (2nd ed.). Malden, M. A.: Blackwell Publishing.

Searle,J.R.(1969).Speech-Acts.Cambridge:Cambridge CUP.

Shuy, R. W. (1997). The Unanswered language Questions about Miranda. Forensic Linguistics, 4(2), 175-196. 
Shuy, R. W. (1998). The Language of Confession, Interrogation, and Deception. Thousand Oaks, London and New Delhi: Sage Publications.

Shuy, R. W. (2005). Creating Language Crimes: How Law Enforcement Uses (and Misuses) Language. New York: Oxford University Press.

Thomas, J. (1986). Discourse Control in Confrontational Interaction. In L. Hikey (Ed.), Pragmatics of Style (pp. 133-156). London: Routledge.

Van Dijk, T. A. (2001). Critical Discourse Analysis. In D. Schiffrin, D. Tannen, \& H. E. Hamilton (Eds.), The Handbook of Discourse Analysis (pp. 352-371). Oxford: Blackwell.

Wang, J. (2006). Questions and the Exercise of Power. Discourse and Society, 17(4), 529-548.

\section{Copyrights}

Copyright for this article is retained by the author(s), with first publication rights granted to the journal.

This is an open-access article distributed under the terms and conditions of the Creative Commons Attribution license (http://creativecommons.org/licenses/by/3.0/). 